\title{
Da hjerteinfarkt ble en multifaktoriell sykdom
}

\author{
Gjesteredaktøren
}

Vi yngre blant de eldste $\mathrm{i}$ det hjerteepidemiologiske miljø pendlet fra 60-tallet og en 30 års tid mellom kolesterolmøter og møter fokusert på blodtrykk eller sigarettrøyking. Hver risikofaktor hadde sin heiagjeng og sin opposisjon. Blodtrykk over valgte grenser var sykdom og skulle behandles uansett. Grensene for hva som var et høyt kolesterol gikk nedover etter hvert som antallet av potente kolesterolsenkere gikk oppover, mens sigaretter var skadelig fra første sigarett da som nå. På 70-tallet hadde enkelte epidemiologer skaffet seg materialer der det ble mulig ikke bare å studere risikoen av enkelte risikofaktorer, men også beregne risikoen forbundet med et multiplum av risikofaktorer. Konseptet at hjerteinfarkt var en multifaktoriell sykdom var da et faktum. Likevel skulle det gå lang tid før hjerteinfarktet ble allment akseptert og håndtert som en multifaktoriell sykdom, slik praksis stort sett er i dag.

Her hjemme ble det konstruert en infarkt risikoskåre som var ferdig til praktisk anvendelse i forbindelse med Osloundersøkelsen i 1972-73. Denne har i litt forskjellige versjoner vært en fast ingrediens i Statens skjermbildefotografering/Statens helseundersøkelser (SSF/ SHUS) sine undersøkelser. Denne risikoskåren er dels brukt som et vitenskapelig verktøy, dels for å plukke ut til nøyere vurdering (etterundersøkelse) de infarkt høyrisiko individene som var røykere, men som ikke ble plukket ut ved rene blodtrykks- eller kolesterolkriterier.

Gjesteredaktøren har ved hjelp av sterke oppfordringer kommet $\mathrm{i}$ besittelse $\mathrm{av}$ et håndskrevet dokument som kort beskriver starten på den norske infarkt risikoskåren (WSC-skåren) med adskillige bemerkninger. Gjesteredaktøren er svært glad for anledningen til å bruke notatet $\mathrm{i}$ dette temanummeret av Norsk Epidemiologi.

\section{"NOEN BEMERKNINGER OM RISIKOSCOREN}

Som nevnt i Bjartveit et al. (Acta Med Scand Suppl 634, 1979) bygger scoren i hovedsak på to prospektive morbiditetsanalyser:

a) I det såkalte "oljeforsøket" (Natvig et al, Scand J Clin Lab Invest, suppl 105, 1968) ble 16000 menn $i$ alder 50-59 fulgt $i$ ett år med 157 førstegangs hjerteinfarkt. Blodtrykk, sigaretter, vekt/høyde (V/H) var registrert av bedriftslege, som også rapporterte nye diagnoser $i$ løpet av observasjonsåret. Infarktinsidens i relasjon til kryss av blodtrykk og sigaretter viste ingen tydelige avvik fra multiplikativ relativ risiko, men tallene var små. En moderat insidenssammenheng med $\mathrm{V} / \mathrm{H}$ ble redusert ved justering for blodtrykk. Serumkolesterol ble bare målt $i$ et tilfeldig $5 \%$ utvalg. Gjennomsnittlig kolesterol viste liten eller ingen sammenheng med blodtrykk og sigaretter, men tydelig med $\mathrm{V} / \mathrm{H}$. b) Ragnar Nicolaysen analyserte i 1958-60 serumkolesterol for et stort antall menn tilknyttet bedriftslegekontorer $i$ Oslo. 3751 menn i alder 40-49 ble fulgt $i$

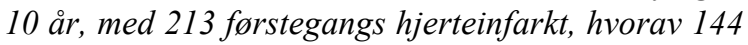
"Definite" (Scand Clin Lab Invest suppl 127, 1972). Serumkolesterol, blodtrykk og V/H, men ikke sigaretter, var registrert ved start. Sammenhengen mellom infarktinsidens og kolesterol var den samme for total som for "definite" og den samme $i$ de to deler av 10-års perioden. Blodtrykk, $i$ motsetning til kolesterol, viste en terskel for infarktinsidens, omtrent ved 140 og $90 \mathrm{~mm}$. Kolesterolsammenhengen var tilnormet parallell for tre blodtrykksgrupper på probitskala. En diskriminantfunksjon ble brukt til sammenligning med en 12-års oppfølging av menn $i$ Framingham. Variablene $i$ Oslo var alder $i$ år, systolisk $i \mathrm{~mm}$, kolesterol $i \mathrm{mg} \%$, V/H kodet 0-4. Framingham inkluderte også hemoglobin, sigaretter og EKG. Koeffisientene for alder og kolesterol var tilncermet de samme i Framingham som i Oslo. For systolisk var koeffisientene høyere i Oslo. Koeffisientene ble hoyere ved å definere systolisk som $\mathrm{mm}$ over 135.

En tredje prospektiv morbiditetsundersøkelse kan nevnes, til tross for at insidensen bygger på selvrapporterte diagnoser fra personer som overlevet observasjonstiden. Statens helseundersøkelser (SHUS) gjennomførte to hjerte-karundersøkelser med 3-5 års mellomrom $i$ fylkene Finnmark, Sogn og Fjordane og Oppland i årene 1974-81. ("Results from second screening", SHUS 1988). Alder 35-49 ved første gangs undersøkelse. Fra 22800 menn som møtte begge ganger, ble det meldt 204 intervallinfarkter, fra 23000 kvinner 24 infarkter. Multippel linecer regresjon, begrenset til de tre scorevariable kolesterol, systolisk og antall sigaretter, ga tverdier:

$\begin{array}{lcc} & M & K \\ \text { Kolesterol } & 8,8 & 3,7 \\ \text { Systolisk } & 4,4 & 1,3 \\ \text { Sigaretter } & 2,7 & 3,0\end{array}$

De individuelle Y-verdier fra regresjonen ble korrelert med à priori risikoscore:

$\begin{array}{lll}\text { Korrelasjon med risk score } & r=, 74 & r=, 72 \\ \text { Korrelasjon med log risk score } & r=, 93 & r=, 93\end{array}$

"Thus, as far as the present very limited follow-up experience goes, the old risk score appears to have served as well for females as for males in age-specific ranking". 
For så vidt gjelder valg av systolisk fremfor diastolisk, kan også nevnes en stensil fra Livsforsikringsselskapenes medisinsk-statistiske institutt ved Ullevål sykehus, juni 1972: "Blodtrykksmålte $i$ Bergen. Den relative prognostiske verdi av systolisk og diastolisk blodtrykk $i$ alder 40-69 år". 14500 menn, 21000 kvinner var fulgt 1963-1970. Antall dødsfall:

\begin{tabular}{lcr} 
& $M$ & \multicolumn{1}{c}{ K } \\
Koronar hjertesykdom + plutselig død & 484 & 181 \\
Apopleksi & 116 & 92 \\
Hypertoni & 19 & 29
\end{tabular}

Linecere diskriminantfunksjoner med alder $i$ år, systolisk og diastolisk i mm, ga som konklusjon:

"Diastolisk blodtrykk har naturligvis sin plass i klinisk medisin, for eksempel ved diagnosen av klappefeil. Men for mange epidemiologiske og prognostiske formål er det neppe umaken verd å registrere og analysere det diastoliske trykk i tillegg til det systoliske”.

De opprinnelige scorefaktorer finnes $i$ Bjartveit et al., 1979, og $i$ Håndbok for hjerte-karundersøkelsen fra 1985. Variablene serumkolesterol, blodtrykk og sigaretter er alle tilgjengelige for intervensjon, forhåpentlig med redusert insidens som resultat. Andre variable har stor betydning for risiko, men er ikke påvirkelige: Kjønn, alder, familieanamnese. Hvorledes slike forhold skal trekkes inn i risikoberegningen, kan saktens diskuteres. Svaret vil bl.a. avhenge av hva man mener à vite om størrelsen på insidensnedsettelsen etter forebyggende tiltak i forskjellige befolkningsstrata. SHUS innførte en kjønnsfaktor på 5,0 da kvinner kom med $i$ undersøkelsene. Senere ble en faktor på 1,5 innført for svar $\mathrm{Ja} /$ Vet ikke på spørsmål om hjerteinfarkt eller angina pectoris hos foreldre eller søsken. Ellers er faktorverdiene for sigaretter litt økt (bortsett fra for 25+ pr. dag) og systolisk $170 \mathrm{~mm}+$ er delt, med 180mm + som høyeste gruppe. Dødelighetsanalyser ved SHUS ligger bak disse justeringer. De nye scorefaktorer står $i$ Håndbok for hjerte-karundersøkelsen fra 1987.

Alder er et spesielt problem. Det er ingen tvil om at en score som inkluderer alder, vil predikere bedre, selv om korrelasjonen mellom alder og kolesterol/blodtrykk er betydelig. Men ikke bare er det spørsmål om effekten av (og forsvarligheten av) intervensjon $i$ forskjellige aldersgrupper. Det kan også vare slik at en utvelgelse til intervensjon ikke primcert tar sikte på à redusere 10års insidens, men på hvor mange leveår som kan vinnes. Den ideelle løsning finnes neppe. Håndboken fra 1987 gir skjønnsmessige alderspesifikke scoregrenser for anbefaling om etterundersøkelse $i$ området 39-49 år, de samme for begge kjønn.
I Nord-Trøndelag i 1989 inviterte SHUS aldersgruppen 65-67 i tillegg til 40-42. Risikoscore ble beregnet også for 65-67 år (men uten familiefaktoren), med de samme faktortall som for 40-42. Som rapporten sier, var denne anvendelse "conjectural". Grensen for anbefaling om etterundersøkelse på grunn av score ble satt vesentlig høyere $i$ eldste gruppe. Forhåpentlig vil det snart foreligge årsaksspesifikke dødelighetsdata $i$ relasjon til score og til de enkelte scorekomponenter.

Rapporten fra hjerte-karundersøkelsen i Finnmark $i$ 1987-88 (ISM skriftserie nr. 28) inneholder bl.a. scorefordelingen (uten familiefaktor) for menn og kvinner $i$ aldersgruppene 20-24, 25-29, ...... 60-62.

Begrunnelsen for den enkle sammenmultiplisering av faktorer var at interaksjonen mellom de tre variable syntes ubetydelig $i$ forhold til de små tall tilgjengelig $i$ 1971-72. Multivariable analyser var på den tid tungvinte - og kolesterol og blodtrykk måtte under alle omstendigheter også sees på separat. Men for dagens statistikere må denne scorefunksjonen fortone seg som gammelmodig. Man kan med rette stille spørsmål om dens langvarige bruk $i$ hjerte-karundersøkelsene er kommet $i$ veien for mer rasjonelle multivariable analyser."

Tilfeldigvis har gjesteredaktøren fisket ut av sitt arkiv et notat: 21. juli 1995 AaT., der parametre fra slike multivariable analyser som Knut Westlund etterlyser er sammenlignet med SHUS infarktrisk. Parametrene for koronardødsfall er estimert på grunnlag av SHUS undersøkelsen Oppland 1. Estimatene er så anvendt på tilsvarende undersøkelser i Sogn og Fjordane 1 og Finnmark 1, der både infarktrisk og estimater fra Cox modellene er delt $\mathrm{i}$ tideler.

Aage Tverdal skriver: "I øverste tiendedel basert på infarktrisk er det flere koronardødsfall enn $i$ øverste tiendedel basert på Cox modell. I de to øverste tiendedeler samlet er det flest dødsfall i Sogn og Fjordane når infarktrisk legges til grunn, mens det $i$ Finnmark er flest når Cox legges til grunn. I de laveste tiendedelene er det få koronardødsfall for samtlige modeller".

Gjesteredaktørens konklusjon: Den infarkt risikoskåre Knut Westlund konstruerte for over 30 år siden har vært et meget nyttig instrument både i Osloundersøkelsen 1972-73 og i alle SHUS-relaterte helseundersøkelser siden. Det ser fortsatt ikke ut til å være konstruert en bedre modell for norske forhold. En modifisert versjon av Framingham risikoskåre har fra år 2000 vært anvendt som ett av mange etterundersøkelseskriterier i SHUS undersøkelsene. Om Framinghamskåren vil være en bedre infarktprediktor enn WSC, gjenstår å se. 